\title{
Collaboration in the Borderlands: The Malpai Borderlands Group
}

\author{
After 10 years of efforts to preserve the open spaces and way of life of the Borderlands \\ Region, the Malpai Borderlands Group is now internationally recognized as an outstanding \\ example of collaborative planning and management of large landscapes.
}

\section{By Larry S. Allen}

\section{Roots of Change}

As our society is now increasingly polarized on the issues of natural resource use and protection of the environment, we endeavor to be at the Radical Center. -Bill McDonald

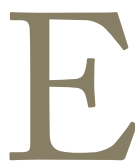
arly in the 1990s, several neighbors along the Mexican border in Southeastern Arizona and Southwestern New Mexico began to meet periodically at Warner and Wendy Glenn's Malpai Ranch. Bill McDonald called the meeting to order by tapping a spoon on his coffee cup. His gaze flitted over the tanned ranchers seated at the Glenn's dinner table. "You all know why we're here. We need to do something before the state and federal bureaucrats decide what to do with us. We all love our land and our lifestyle, and we're under siege from misguided environmentalists, who want to destroy our way of life with their upcoming 'Cattle Free in 93' campaign on the public lands." Other concerns included a top-down approach to management on the part of the myriad of state and federal land management agencies. Rancher Drummond Hadley invited some of his friends from the environmental community in New Mexico to join in the discussions, and several points of agreement were discovered. Strongest agreement was in the areas of preservation of open space and the need to restore fire as a functioning ecological process. It was agreed that livestock grazing requires open space and that preservation of the ranching industry is important to prevent habitat fragmentation.

The Malpai Planning Area includes 2 valleys at an elevation of about 4,000 feet, which support semidesert grassland and Chihuahuan desert scrub; 1 higher grassland valley (about 5,000 feet) with plains grassland; and 2 mountain ranges. Montane habitats include pinyon, juniper, live oaks,

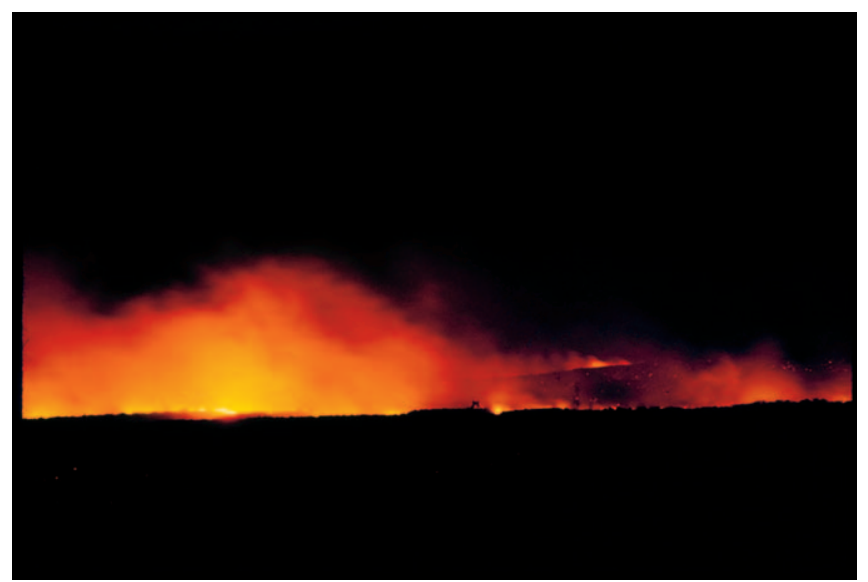




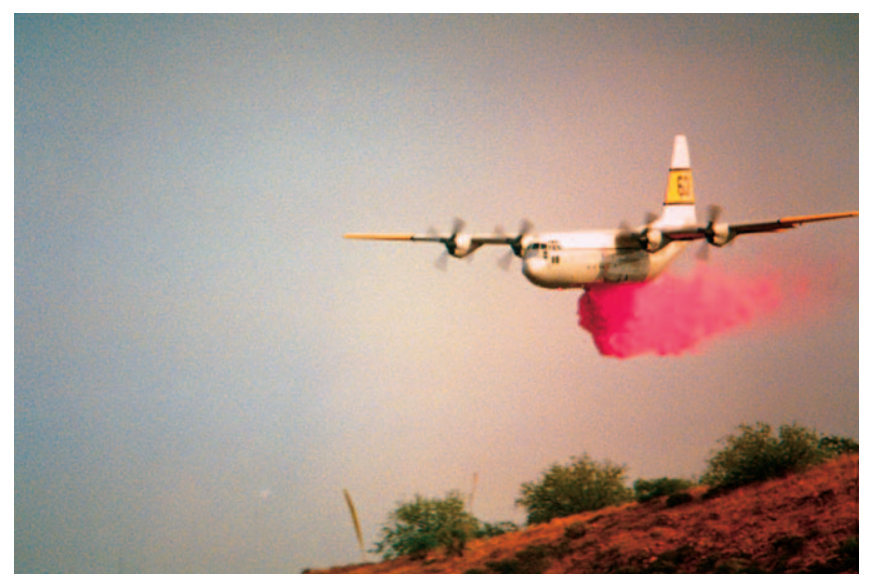

pines, and Douglas fir. Rainfall ranges from 12 to 25 inches annually. A mixture of native grasses produces from 1,000 to 2,500 pounds of forage per acre in an average year.

As this discussion group was forming, one event provided a catalyst for action. An airline pilot reported a wildfire along the road on the Rocker M Ranch. The fire was within an area that had been treated with herbicides to improve forage production and soil stability several years before. Shrubs were beginning to reinvade the site, and most neighbors perceived the fire as beneficial to maintain the brush control project. Adjacent to the area was a complete lack of fuels, with no danger of spread of the fire. Arizona State Land Department requested help from the US Forest Service, and an intensive suppression effort was conducted over the objections of the landowner/grazing permittee.

This fire event motivated the "Malpai Group" to poll the neighbors and produce a map indicating the desires of each local rancher concerning fire suppression. The map had 3 zones: 1) suppress immediately, 2) consult with owner, and 3) monitor. The group then requested a meeting with agency heads to discuss suppression policies. Representatives of Arizona State Land Department, the New Mexico State Forester, the Forest Service, the Soil Conservation Service, and the Bureau of Land Management in both states met with the group at Gray Ranch, New Mexico. The ranchers were pleasantly surprised to learn that agency personnel were in agreement that a change in suppression policy was needed. All agencies agreed to use a "Confine/Contain" strategy and to participate in landscape-scale fire planning. The result has been more than 250,000 acres of beneficial fires since 1993. The Malpai Borderlands Group (MBG) continues to annually interview the neighbors and to provide the agencies with an updated suppression map.

\section{The Malpai Borderlands Group}

It soon became apparent that the informal group needed more structure, and a meeting of all neighbors was called. The group was incorporated as a nonprofit corporation called The Malpai Borderlands Group and the following goal statement was developed:
Our goal is to restore and maintain the natural processes that create and protect an unfragmented, bealthy landscape to support a diverse, flourishing community of buman, plant and animal life in our borderlands region.

Together we will accomplish this by working to encourage profitable ranching and other traditional livelihoods, which will sustain the open space nature of our land for generations to come.

\section{Fire Planning}

The first major project undertaken by the group was a landscape-scale fire plan for the approximately 800,000-acre Malpai Borderlands Region. It was decided to divide the area into 4 planning units: 1) private and state lands in the New Mexico "boot-heel," 2) federal lands in the Peloncillo Mountains, 3) state and private lands in Arizona's San Bernardino Valley, and 4) Bureau of Land Management (BLM) and state lands in the Northwest portion of the planning area. Concurrently, supporters in the Mexican State of Sonora were undertaking similar planning.

- New Mexico State Forestry Department assumed responsibility for the "Boot-heel Plan" with close support from the Las Cruces District of BLM and the Animas Foundation. This plan was quickly completed, and it has undergone 1 revision.

- Coronado National Forest undertook planning for the federal lands (the Peloncillo Programmatic Fire Plan) with support from BLM's Safford District. This planning process has been under way since early 1997 . Progress has been slow and frustrating. Required consultation between the Forest Service and US Fish and Wildlife Service was completed in the spring of 2005, and the plan has been incorporated into the Coronado Forest Plan. Modification of BLM plans has not yet occurred.

- Arizona State Land Department and US Department of Agriculture (USDA) Natural Resource Conservation Service (NRCS) initiated planning for the San Bernardino Valley. Retirement of a key NRCS person has resulted in delays in completion.

- Safford BLM district assumed responsibility for the northwestern part of the area. This plan has not yet been initiated.

Fire planning includes consideration of wildfire suppression, management fires, and management ignited prescribed burns. This continues to be a priority for the Malpai Group.

\section{Help From Nongovernmental Organizations}

At the time of the formation of the Malpai Borderlands Group, The Nature Conservancy (TNC) purchased Diamond A Ranch in an attempt to preserve the tremendous biodiversity and wildlife habitats of the area. TNC immediately undertook an inventory and planning process for the ranch. Management of the 330,000-acre ranch soon became a significant drain on the financial resources of TNC, and it began to seek a "conservation buyer." This was a new 
approach for the conservation group, which has since become a common procedure.

TNC Vice President John Cook was sent to New Mexico to oversee the sale of this property with a conservation easement. After several months of seeking a suitable buyer, Drummond Hadley, one of the founding members of the Malpai Borderlands Group, was able to create a family foundation (the Animas Foundation) and purchase Diamond A Ranch, with conservation easements. In the process, John Cook became friends with the Hadley family and began to meet some of the neighbors.

The Animas Foundation has an objective of demonstrating sustainable agriculture in harmony with a healthy environment - an idea that was shared by the Malpai Group. The Animas Foundation became a strong supporter of the Malpai Group, with 2 of the Hadleys currently on the Board of Directors. John Cook's vast experience in organization and fund-raising proved invaluable to the group during the formative stages. He is currently a board member. The help and support from John Cook and TNC has long been one of the strengths of the Malpai Group.

\section{Collaborative Management in the Borderlands}

The group quickly realized that cooperative management of this complex landscape would require close liaison with the involved land management agencies. They persuaded the USDA Soil Conservation Service (now the NRCS) to appoint Range Conservationist Ron Bemis to be an agency representative. USDA Forest Service was convinced to make Range Ecologist Larry Allen available for a similar position. These 2 positions soon evolved into full-time jobs for Ron and Larry.

Many of the issues under consideration were based on science and the group came to the conclusion that all decisions needed to be based on the best available science. Board member Ray Turner was a respected ecologist and author, and he contributed to the organization of a science committee. Research Foresters Leonard DeBano and Carl Edminster, of the Forest Service's Rocky Mountain Experiment Station, were instrumental in establishing contacts and providing funding for needed research, including Dr Liz Slausen's study of fire impacts on Palmer Agave and Andy Holycross' studies of the New Mexico Ridge-nosed Rattlesnake. Sometime later, TNC Botanist Peter Warren was hired part-time, and Dr Charles Curtin was contracted to coordinate some of the science effort. Dr Ben Brown currently coordinates the science effort. Scientists from a number of agencies, universities, and private institutions have contributed to the group's understanding of the ecosystem.

Neighboring ranchers were encouraged to meet with the group and participate in planning for the future of the Borderlands. Presently, 10 of 13 board members are from the ranching community. An attempt has been made to include all federal, state, and local agencies involved in the area, and
Table 1. Organizations involved in the Malpai Borderlands Group
United States

Department of

Agriculture

Coronado National

Forest

Rocky Mountain

Experiment Station

Natural Resource

Conservation Service

Cooperative

Extension Service

Agricultural Research

Service

United States

Department of Interior

Bureau of Land

Management -

Safford

Bureau of Land

Management - Las

Cruces

US Geological

Survey - Desert Lab-

Tucson

US Fish and Wildlife

Service-AZ and NM

The Nature

Conservancy

The Animas Foundation

Ranching Community of Arizona, New

Mexico,

and Sonora
Hidalgo County, New Mexico

Cochise County, Arizona
Arizona State Land Department

New Mexico State Land Department

New Mexico State Forester
Arizona Department of Game and Fish

New Mexico

Department of Game and Fish

\begin{tabular}{|c|c|}
\hline and Sonora & $\begin{array}{l}\text { University of New } \\
\text { Mexico } \\
\text { New Mexico State } \\
\text { University }\end{array}$ \\
\hline & $\begin{array}{l}\text { Secretary of the } \\
\text { Environment - Sonora, } \\
\text { Mexico }\end{array}$ \\
\hline
\end{tabular}


academia, nongovernmental organizations, and interested citizens as collaborators. This diversity has created a strong and effective organization. Involved organizations are listed in Table 1.

\section{On-the-Ground Management}

The Malpai Group has always considered itself to be a "hands-on" management organization as opposed to a planning group. While collaborative planning has been under way, the group has initiated a number of projects.

\section{Shrub Control}

Encroachment of woody plants into grasslands and an increase in the density of woodlands are some of the major problems facing the group. Areas on Malpai Ranch and Magoffin Ranch were cleared of desert shrubs and seeded to native grasses. Several experimental plots have been estab-

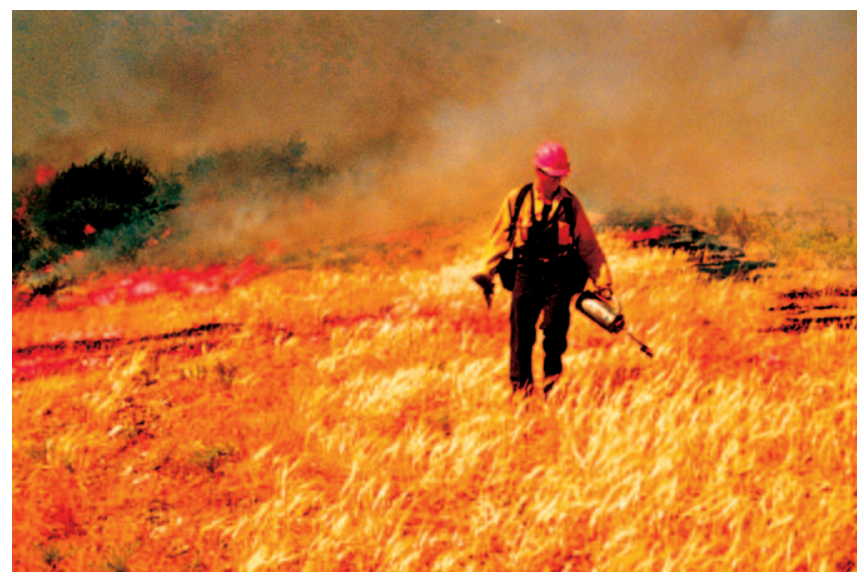

lished in the area to test shrub-control techniques. Three significant, prescribed burns- the 6,000-acre Baker Burn, the 12,000-acre Maverick Burn, and the 43,000-acre Baker II Burn - have been conducted to thin shrubs and trees and reduce fuel loading. The Baker II Burn is thought to be the largest management-ignited fire in US history.

\section{Wildlife Management}

Several miles of old, net-wire, domestic sheep fence were replaced with a state-of-the-art, "wildlife friendly," 4-strandbarbwire fence in a cooperative project jointly funded by a rancher, the Malpai Borderlands Group, and the BLM.

New Mexico Department of Game and Fish reintroduced desert bighorn sheep on the Miller Ranch in the Peloncillos. Bill and Carol Miller conduct much of the monitoring of the sheep by air and ground.

\section{Endangered Species}

Ranchers Matt and Anna Magoffin discovered 2 populations of the endangered Chiricahua Leopard Frog on their private land. When a drought in 1994 threatened to dry up the water source for the frogs, the Magoffin Family began to haul water

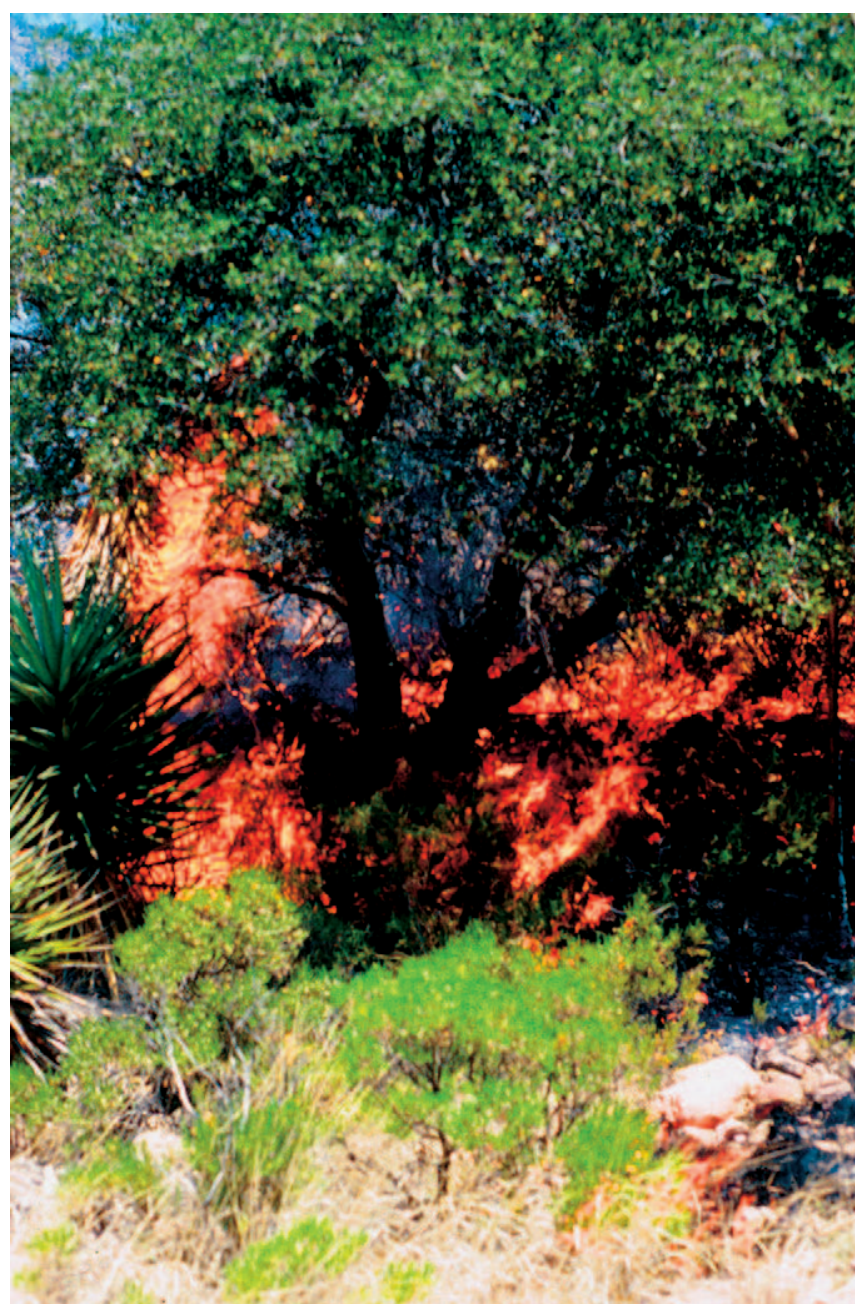

to a pond. They furnished about 1,000 gallons a week all summer, and the frogs were able to survive. The Malpai Group reimbursed the Magoffins for a portion of their expenses. This "frog project" has now grown into a major effort involving Arizona Game and Fish, US Fish and Wildlife Service, the University of Arizona, and biology classes in Douglas, Arizona. Several agency- and Malpai Borderlands Group-supported projects enabled the Magoffins to drill wells

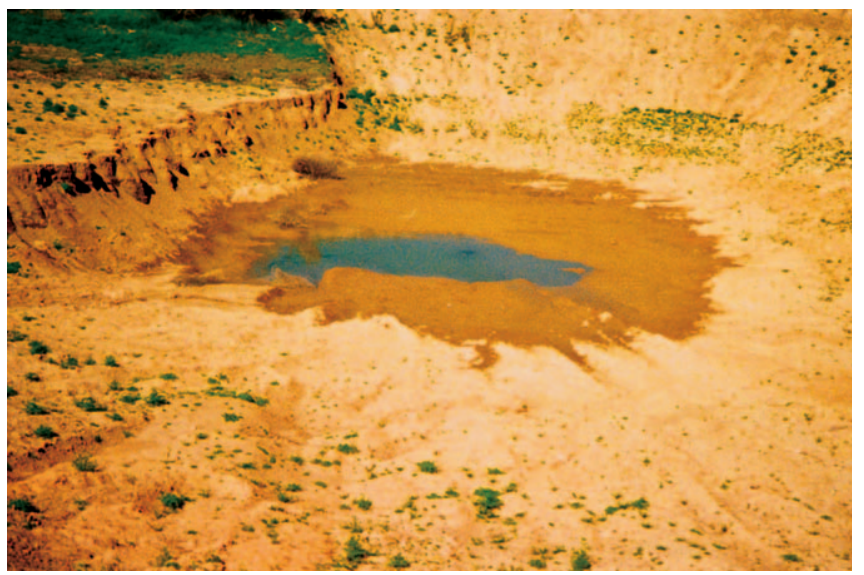




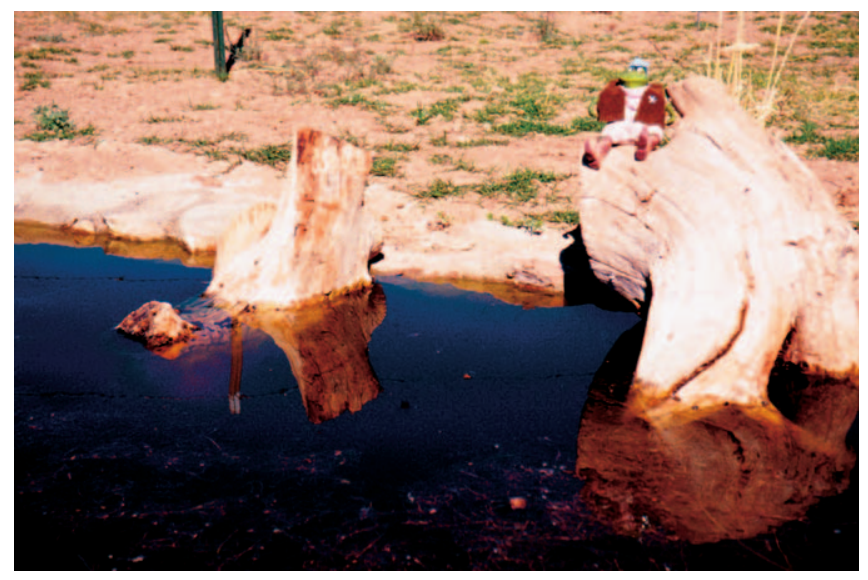

and to provide pipelines and ponds to keep the frogs prospering, while providing much-needed cattle water.

Rancher and Guide Warner Glenn encountered a very rare Mexican Jaguar while hunting mountain lions along the New Mexico-Arizona state line in March 1996. He obtained several excellent photos of this magnificent cat (the

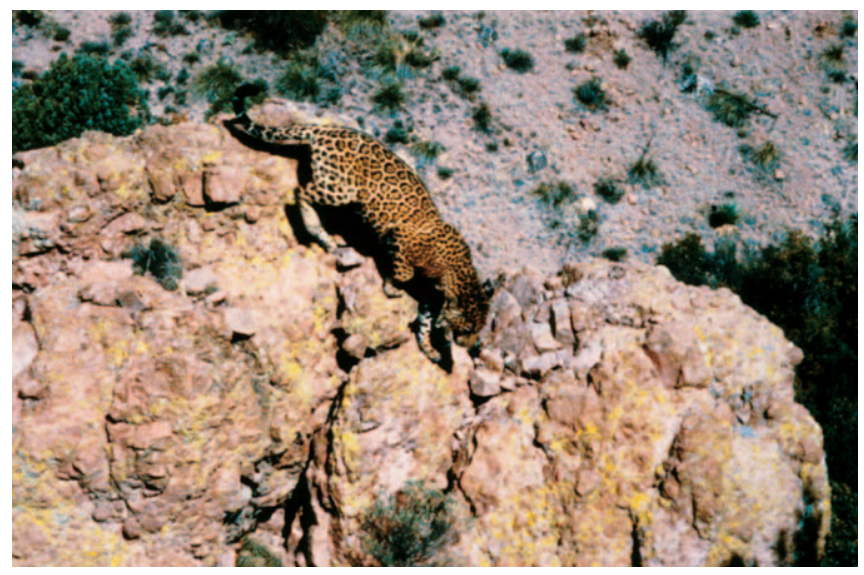

first ever taken in the United States). Warner's photos were published in the book Eyes of Fire. A portion of the proceeds from that book is placed in a fund to compensate ranchers who can document losses of livestock to jaguars and to fund jaguar research in Arizona, New Mexico, and the nearby Sierra Madre of Mexico. Efforts of the Malpai Group to encourage research and management of this animal have resulted in an active Jaguar Management team in the Borderlands region, under the leadership of Arizona Game and Fish Department.

\section{The Grassbank}

Drummond Hadley, of the Animas Foundation, originated a concept called "Grassbanking." Under this practice, ranchers with more forage than currently needed make grass available for neighbors with needs. This practice has been used to alleviate drought problems and to provide needed rest from grazing to facilitate improved range management. The

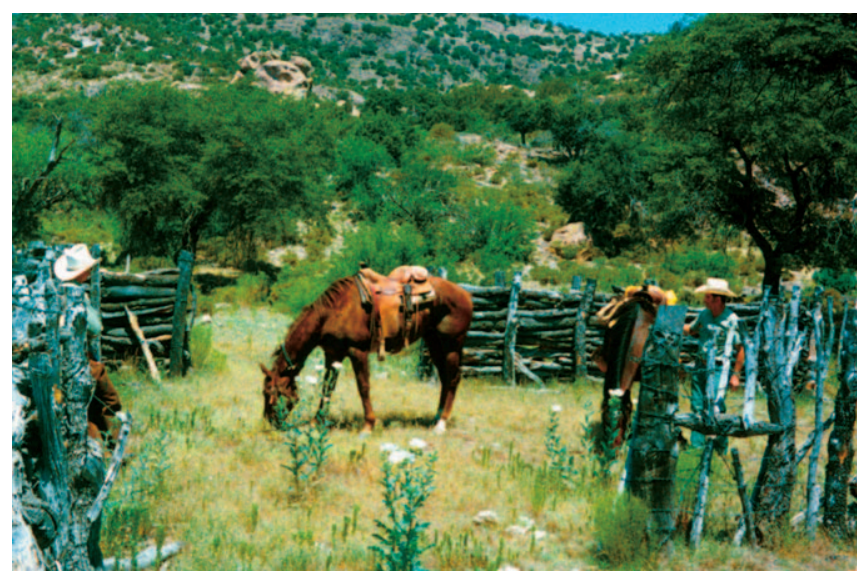

Malpai Group finds available grass and pays grazing fees to the landowner in return for conservation easements on involved private lands to promote improved range management practices. This idea is spreading throughout the West and is currently being implemented on at least one National Forest grazing allotment in New Mexico.

\section{Conservation Easements}

The Malpai Group has protected 77,000 acres of private land, affecting 204,000 additional acres of commingled state and federal land on 13 ranches, from development through the use of conservation easements. Other easements are currently in the discussion stage. The combination of these easements and the TNC easement on Gray Ranch results in considerably more than half the planning area under protection at this time.

\section{Beef Marketing}

The group is actively seeking opportunities to improve the profitability of ranching through innovative marketing strategies. They stay in touch with innovative rancher groups throughout the country. To date, no system has been discovered that fits the unique situation in the borderlands. Currently under study are such ideas as "grass-fed beef" and "organic beef." American consumers are willing to pay a premium for these specialty products, especially if they are produced in concert with significant conservation efforts.

\section{Can the MBG Be Duplicated Elsewhere?}

- Yes, but...

- Must be a local, grassroots initiative, not a government project.

- Must have dedicated agency representatives.

- Must have flexibility-every area is different.

Author is a Board Member of Malpai Borderlands Group and retired from the USDA Forest Service, PO Box 66736, Albuquerque, NM 87193, larryallen350@earthlink.net. 